\title{
Original Paper \\ Functional diversity of plant communities at edge and interior of a submontane Atlantic Forest: greater functional than compositional stability
}

\author{
Ana Paula Lima do Couto-Santos ${ }^{1,6}$, Lia D’Afonsêca Pedreira de Miranda ${ }^{2,4}$, Davi Rodrigo Rossatto ${ }^{3}$ \\ \& Ligia Silveira Funch ${ }^{2,5}$
}

\begin{abstract}
We compared the functional diversity of community at edge and interior areas of an Atlantic forest fragment to test the hypothesis that higher functional diversity exists along edges - in consonance with their higher abundance and floristic diversity as compared to the interior of the forest. By considering a set of vegetative, reproductive and phenological traits and ecosystem service aspects of edge and interior environments, we defined plant functional groups using Cluster Analysis, followed by a silhouette width analysis, together with functional diversity indices of richness, divergence, evenness and dispersion. The main functional groups formed were similar between the edges and interior. Functional richness was the only index that demonstrated differences between edge and the interior. Alterations were perceived in relation to species richness and the Shannon index. Edge effects were not significant in the formation of functional groups. In contrast to our original hypothesis, similar groups were formed both along the edge in the interior - indicating that species played similar ecological roles in both environments, with similar responses to different environmental factors - so that forest edges were colonized by a series of different species that maintained diversity patterns similar to those found in the forest interior.
\end{abstract}

Key words: artificial borders, Atlantic Forest, Chapada Diamantina, forest fragmentation, functional diversity.

\section{Resumo}

Comparamos a diversidade funcional de comunidades em áreas de borda e interior de um fragmento de Floresta Atlântica para testar a hipótese de que existe maior diversidade funcional ao longo da borda em consonância com sua maior abundância e diversidade florística quando comparada com o interior da floresta. Considerando um conjunto de características vegetais, reprodutivas fenológicos, e serviços ecossistêmicos dos ambientes de borda e interior, foram definimos grupos funcionais de plantas usando Análise de Cluster, e por uma análise de silhueta, juntamente com índices de diversidade funcional de riqueza, divergência, uniformidade e dispersão. Os principais grupos funcionais formados são semelhantes ao longo da borda e do interior. Riqueza funcional foi o único índice de diversidade que apresentou diferença entre borda e interior. Alterações foram percebidas em relação à riqueza de espécie e ao índice de Shannon. Efeitos de borda não foram significativos na formação de grupos funcionais. Em contraste com nossa hipótese original, grupos semelhantes foram formados tanto na borda quanto no interior, indicando que espécies desempenharam papeis ecológicos semelhantes em ambos ambientes, com respostas similares a diferentes fatores ambientais, de modo que as bordas da floresta foram colonizadas por uma série de espécies diferentes que mantinham padrões de diversidade como os encontrados no interior.

Palavras-chave: borda artificial, Floresta Atlântica, Chapada Diamantina, fragmentação florestal, diversidade funcional.

\footnotetext{
${ }^{1}$ Universidade Estadual do Sudoeste da Bahia, Depto. Ciências Exatas e Naturais, Itapetinga, BA, Brasil. ORCID: <https://orcid.org/0000-0003-4349-7136>.

${ }^{2}$ Universidade Estadual de Feira de Santana, Depto. Ciências Biológicas, Feira de Santana, BA, Brasil.

${ }^{3}$ Universidade Estadual Paulista Júlio de Mesquita Filho, Depto. Biologia Aplicada a Agropecuária, Jaboticabal, SP, Brasil. ORCID: <https://orcid.org/00000001-9510-8345>

${ }^{4}$ ORCID: <https://orcid.org/0000-0002-1841-1663>.

${ }^{5}$ ORCID: <https://orcid.org/0000-0001-7096-0187>.

${ }^{6}$ Author for correspondence: aplcouto@yahoo.com.br
} 


\section{Introduction}

Forest ecosystems have been historically and continually devastated, leading to the reduction of biodiversity. Many studies indicate (Murcia 1995; Mendes et al. 2016; Melo et al. 2019) that ecosystem fragmentation and the edge effect contribute to this loss. Forest fragmentation creates abrupt edges that can severely alter microclimatic conditions (Laurance et al. 2002; Santos et al. 2008). Among the resulting changes, perhaps the most striking are related to variations in solar irradiation that increase the temperature and affect soil and air humidity and wind velocity (Tabarelli et al. 2008; Laurance et al. 2011; Carvalho et al. 2016). Increasing fragmentation reduces intact areas and leads to interruptions of dispersal, migration, and can even prevent plant establishment (Cordeiro \& Howe 2001). Additionally, the forest edges become altered, with previously protected forest nuclei becoming increasingly exposed to external conditions that provoke progressive biodiversity erosion and the degradation of ecosystem functioning (Murcia 1995; Tabarelli et al. 1999; Laurance et al. 2006).

Changes in floristic composition can also be linked to functional aspects, since environmental changes would result in greater recruitment (or reduced mortality) of light tolerant species near new forest edges (Laurance et al. 2006; Tabarelli et al. 2008; Santos et al. 2012; Girão et al. 2007). The various modifications of the flora and fauna resulting from fragmentation can influence biotic interactions and affect ecological functions such as predation, parasitism, herbivory, pollination, seed dispersal and ecosystem services (Galetti et al. 2003; Lopes et al. 2009; McCauley et al. 2013) as well as promote changes in the reproductive traits of plants (Girão et al. 2007). Phenology, pollination and dispersal modes, especially abiotic syndromes, have been associated with plant strategies that coexist in seasonal contexts and affect ecosystem services (Jara-Gerrero et al. 2011; Perez-Harguindeguy et al. 2013; Sfair et al. 2016). Researchers have reported significant differences in the reproductive phenologies of species as result of the formation of both natural and anthropogenic edges (Cunnigham 2000; Athayde \& Morellato 2014; Pires et al. 2014; Menezes et al. 2018). Edge creation can strongly affect species composition and phenodynamics, strongly influence community functioning and ecosystem processes, as well as decrease the functional diversity of forest patches (Girão et al. 2007).

Numerous studies have shown that edge influences represent one of the most important drivers of species losses in fragmented forests throughout the world through, for example, invasion of alien species and higher nest predation (e.g., Haddad et al. 2015; Esseen et al. 2016). Few studies, however, have evaluated the impacts of edge effects on plant functional groups composition and community functional diversity, as most studies have only assessed changes in arboreal forest components (Girão et al. 2007; Carreño-Rocabado et al. 2012; Maeshiro et al. 2013). The Brazilian Atlantic Forest domain comprises ombrophilous and semi-deciduous forests, including small disjunct forests in the Espinhaço Range (OliveiraFilho \& Fontes 2000; Silveira et al. 2019) that are surrounded by vegetation matrices dominated by savanna and rupestrian grasslands (Funch et al. 2009; Silveira et al. 2016). Those forest patches represent critically endangered biodiversity hotspots harboring numerous endangered species (Coelho et al. 2018). Such threat mainly is due to anthropogenic factors and forest fragmentation that have led to the destruction and loss of biodiversity.

Linear infrastructure installations, such as the construction of roads, pipelines, and highvoltage transmission lines, alter natural landscapes, and often require the deforestation of corridors inside forests, thus creating linear edges (Murcia 1995). As linear edges were found to impact the floristic composition, diversity, and abundance of arboreal species of submontane seasonal forest in the Chapada Diamantina (Couto-Santos et al. 2015), we sought to detect linear edge effects on the functional aspects of a tropical seasonal forest community, considering all of its growth forms.

In this study, we evaluated whether the transmission lines (a corridor of approximately $10 \mathrm{~m}$ wide) established in the 1960 s causes edge effects that alter the functional diversity patterns and functional groups compositions of forest edge and interior areas of inland Atlantic Forest in Chapada Diamantina, in northeastern Brazil. As such, we addressed the following questions: (i) What are the main functional groups in the submontane forest, and how do they vary between the forest edge and interior? (ii) Are there significant variations in functional diversity between the edge and interior in relation to species richness and diversity? (iii) Are the co-occurring species in the two areas assembled into distinct functional groups? 


\section{Material and Methods}

Study area

The Chapada Diamantina Mountains (part of the larger Espinhaço Range in northeastern Brazil) shows high floristic diversity associated with various vegetation types (Couto et al. 2011), including submontane seasonal forest growing on deep, yellow-red latosols. This tall forest on the eastern flank of the Chapada Diamantina is set within a matrix of open vegetation (cerrado and caatinga). Significant percentages of that forest have been cleared in the last 30 years for timber and charcoal extraction, the construction of highways and electric transmissions networks, and especially for pasture formation - leading to fragmentation and biodiversity losses (Funch et al. 2005, 2008; Couto et al. 2011; Couto-Santos et al. 2015).

The study was conducted between April and September/2015 in a forest fragment resulting from anthropic action about 1,000 ha growing on deep yellowish-red latosols, within the boundaries of the Chapada Diamantina National Park, on the eastern flank of the Chapada Diamantina Mountains, Bahia state, Brazil. The study area

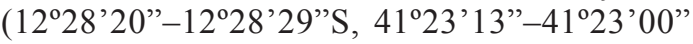
W) is divided by two parallel corridors of highvoltage transmission lines (each a clear-cut corridor approximately $10 \mathrm{~m}$ wide, with regular management due to the transmission lines) established in the 1960s. The vegetation there is original submontane seasonal forest, with the presence of emergent trees up to $26 \mathrm{~m}$ tall, including Protium heptaphyllum Aubl. Marchand (Burseraceae), Maprounea guianensis Aubl. (Euphorbiaceae), Hirtella glandulosa Spreng. (Chrysobalanaceae), and Aspidosperma discolor A. DC. (Apocynaceae), with poorly defined stratification, and a well-illuminated understory predominantly composed of young individuals of upper canopy species and species of Rubiaceae, Melastomataceae and Poaceae. Vines are abundant, but epiphytes and hemi-parasites are rare (Couto et al. 2011).

The regional landscape is undulating, with altitudes varying between 400 and $600 \mathrm{~m}$, with clayey latosols containing only low amounts of organic material (Funch et al. 2005). The regional climate is classified as Aw (Alvares et al. 2014), with heavy rains during the Austral summer (November through January) and a secondary rainfall peak from March to April; the summers are rainy, and the winters are dry. Monthly rainfall varies from $35 \mathrm{~mm}$ (July through August) to $184 \mathrm{~mm}$ (December), with mean monthly rainfall rates exceeding $100 \mathrm{~mm}$ during the rainy season. Mean monthly temperatures vary from approximately $18{ }^{\circ} \mathrm{C}$ during the coldest months (April through September) to approximately 22 ${ }^{\circ} \mathrm{C}$ during the warmest months (October through February). Those environmental conditions typify the vegetation at the study site as Submontane Seasonal Forest (IBGE 2012).

\section{Species surveys}

An earlier floristic and phytosociological survey undertaken in the same area (Couto-Santos et al. 2015) established thirty randomly placed $10 \times 10 \mathrm{~m}$ plots $(0.3$ ha total $)$, with 15 plots near the linear edge formed by the power line $(0-100$ $\mathrm{m}$ from the power line) and 15 plots in the forest interior ( $>150 \mathrm{~m}$ from the power line), with different distances from the linear edger and with unequal distances between them.

Trees, shrubs, vines, herbs, and epiphytes (71 species) were selected for the functional study according to their abundance, importance value and frequency in the area, corresponding to $75 \%$ of the total number of species found in the study plots (Couto-Santos et al. 2015). Only individuals $(n=491)$ located within the plots were selected for this study. All of the taxa studied were collected and herborized when in their reproductive phases, following Mori et al. (1989), and subsequently deposited in the HUEFS herbarium. The identifications of the plant materials were made by comparisons with specimens housed at the HUEFS and by consulting specialists.

\section{Functional aspects}

As we were interested in changes of forest community functionality and associated ecosystem services caused by linear edges, we measured traits related to pollination, seed dispersal, and carbon storage (McCauley et al. 2013) (Tab. 1) among species that were collected during a phenological and phytosociological study undertaken by CoutoSantos (2014); complementary data concerning pollination and dispersal syndrome were obtained from the literature and used to identify functional groups (FG). A matrix was established describing the binary and continuous functional characteristics of the species in the edge and interior areas (Violle et al. 2017) (Tab. 1). After converting the trait matrix into a numerical matrix, the data was 
Table 1 - Functional traits used for describing the plant species at the edge and in the interior of a submontane seasonal forest, Chapada Diamantina, Northeastern Brazil.

\begin{tabular}{|c|c|c|c|}
\hline & Functional traits & Traits description & $\begin{array}{l}\text { Associated ecosystem } \\
\text { services }\end{array}$ \\
\hline \multirow[t]{2}{*}{ Structural features } & Life forms & $\begin{array}{l}\text { Tree (1), shrub (2), vine (3), } \\
\text { terrestrial herb (4), epiphyte (5) }\end{array}$ & Carbon storage \\
\hline & Stratum & Canopy (1), sub canopy (2) & Carbon storage \\
\hline \multirow{6}{*}{ Phenological patterns } & Leaf phenology & $\begin{array}{l}\text { Perennial (1), semi-deciduous (2) } \\
\text { deciduous (3), leafless (4) }\end{array}$ & Carbon storage \\
\hline & Reproductive phenology & & \\
\hline & Synchrony & $\begin{array}{l}\text { Asynchronic (1), low synchronic (2) } \\
\text { high synchronic (3) }\end{array}$ & \\
\hline & Frequency & $\begin{array}{l}\text { Continual (1), subannual (2), annual (3) } \\
\text { supra-annual (4) }\end{array}$ & $\begin{array}{l}\text { Pollination and seed } \\
\text { dispersal }\end{array}$ \\
\hline & Regularity & Irregular (0) regular (1) & \\
\hline & Duration & Brief (1), intermediate (2), extended (3) & \\
\hline \multirow{3}{*}{ Reproductive aspects } & Dispersal syndrome & $\begin{array}{l}\text { Zoochory (1), anemochory (2), } \\
\text { autochory (3) }\end{array}$ & Seed dispersal \\
\hline & Pollination syndrome & $\begin{array}{l}\text { Anemophily (1), cantharophyly (2), } \\
\text { phalenophily (3), melittophily (4), } \\
\text { ornithophily (5), psicophily (6), } \\
\text { zoophily not specialized (7) }\end{array}$ & Pollination \\
\hline & Pericarp texture & Dried fruit (0), fleshy fruit (1) & Seed dispersal \\
\hline
\end{tabular}

scaled, and the functional groups were defined by Hierarchical Cluster Analysis. We used the Gower distance (Pla et al. 2012) and the average linkage in the NbClust package (Charrad et al. 2015) to form the FG. The number of ideal groups per local (border or interior) was analyzed using the silhouette width based on the silhouette function (Borcard et al. 2018). All cluster analysis was performed using free $\mathrm{R}$ version 3.6.1 software ( $\mathrm{R}$ Core Team 2019). The cophenetic correlation was calculated according to the methodology proposed by Bussab \& Morettin (2017), with an agreement measure between the groupings obtained and the original matrix of distances being obtained using PAST software (Hammer et al. 2001).

There are several methods and indexes for calculating functional diversity (Song et al. 2014). Those indices differ in their mathematical properties, in that they emphasize the location or dispersion of measures, consider single or multiple characteristics, and include abundances in the trace values and functional components (richness, divergence and evenness) (Mason et al. 2005; Mouch et al. 2010; Casanoves et al. 2011). The indexes of Functional richness (FRic - represent the trait space filled by the community), Functional divergence (FDiv - quantify how the trait values are spread along the range of a trait space), Functional evenness (FEve - measures the regularity of spacing between species in the trait space as did the univariate), and Functional dispersion (FDis - is a multidimensional index based on multitrait dispersion) (Casanoves et al. 2011), were used to quantify the total functional diversity of the system (FD) (Petchey \& Gaston 2002), considering that differences in those functional indexes would be related to changes in ecosystem services caused by linear edges (Cadotte et al. 2011).

Those calculations were performe using FDiversity software <http://www.fdiversity. nucleodiversus.org > (Casanoves et al. 2011), including the abundance of each species per plot. 
Statistical analyses

Permutational multivariate analysis (PERMANOVA) was performed to verify the existence of significant floristic difference between edges and interior (Anderson 2001). One-Way ANOVA was used to test for differences in functional diversity between edge and interior areas and was used to test the relationships between the functional diversity indices and species richness (numbers of species - S), as well as the diversity (Shannon - Wiener $\left(H^{\prime}\right)$ in each plot. Those analyses were performed using BioEstat5.3 software (Ayres et al. 2007), considering, in all cases, $\alpha=0.05$. The normality of data was evaluated using the ShapiroWilk test $(P>0.05)$.

\section{Results}

A total of 61 species were found in the forest edge sites and 50 species in the forest interior
(Appendix S1, available on supplementary material $<$ https://doi.org/10.6084/m9.figshare.13683961. v1>); 40 of those species were common to both environments. The edge demonstrated a cophenetic correlation of 0.79 and the interior 0.82 . The main functional groups formed at the edge and in the forest interior (as determined by Cluster analysis) were defined based on life forms, stratum, leaf phenology, and fruit pericarp consistency (Tab. 2). The floristic difference between edge and interior was confirmed by PERMANOVA $(\mathrm{P}<0.001)$.

Cluster analysis revealed the existence of two principal functional groups (Fig. 1a) along the edge; the first (BG1) comprised 47 species, and the second (BG2) 13 species (Fig. 2). In terms of their functional traits, group BG2 was found to be formed by understory vines, shrubs, herbs, and perennial epiphytes producing dry fruits. BG1

Table 2 - Characterization of plant functional groups at the edge and in the interior of a submontane seasonal forest, Chapada Diamantina, Northeastern Brazil.

\begin{tabular}{|c|c|c|c|c|}
\hline & Group (G) & Subgroup (SG) & Species (n) & Predominant characters \\
\hline \multirow{6}{*}{ Edges } & \multirow{4}{*}{ BG1 } & BSG1 & $3 \mathrm{sp}$ & $\begin{array}{l}\text { Shrubs, sub canopy, flowering and fruiting annual, zoochory and } \\
\text { fleshy fruit }\end{array}$ \\
\hline & & BSG2 & $26 \mathrm{sp}$ & $\begin{array}{l}\text { Trees, canopy, perennial, annual reproductive phenology, zoochory } \\
\text { and fleshy fruit }\end{array}$ \\
\hline & & BSG3 & $10 \mathrm{sp}$ & $\begin{array}{l}\text { Vines, canopy, perennial, high synchronic reproductive } \\
\text { phenophases, melittophily }\end{array}$ \\
\hline & & BSG4 & $8 \mathrm{sp}$ & $\begin{array}{l}\text { Trees, canopy, perennial, annual reproductive phenology zoochory } \\
\text { and anemochory, dried fruit }\end{array}$ \\
\hline & \multirow{2}{*}{ BG2 } & BSG5 & $2 \mathrm{sp}$ & $\begin{array}{l}\text { Vines and shrubs, sub canopy, perennial, intermediate } \\
\text { phenophases, anemochory, dried fruit }\end{array}$ \\
\hline & & BSG6 & $11 \mathrm{sp}$ & $\begin{array}{l}\text { Herbs and epiphytes, sub canopy, perennials, melittophily in } \\
\text { anemophily,dried fruit }\end{array}$ \\
\hline \multirow{6}{*}{ Interior } & \multirow{4}{*}{ IG1 } & ISG1 & $8 \mathrm{sp}$ & $\begin{array}{l}\text { Trees, canopy,annual reproductive phenology of intermediate } \\
\text { duration melittophily, dried fruit }\end{array}$ \\
\hline & & ISG2 & $9 \mathrm{sp}$ & $\begin{array}{l}\text { Vines, canopy, perennial,high synchronic reproductive } \\
\text { phenophases, melittophilous, dried fruit }\end{array}$ \\
\hline & & ISG3 & $15 \mathrm{sp}$ & $\begin{array}{l}\text { Trees, canopy, perennial, low synchronic reproductive } \\
\text { phenophases, zoochory, fleshy fruit }\end{array}$ \\
\hline & & ISG4 & $7 \mathrm{sp}$ & $\begin{array}{l}\text { Trees,canopy, semi-deciduous, annualreproductive phenophasesof } \\
\text { intermediate duration,melittophily, zoochoric, fleshy fruit }\end{array}$ \\
\hline & \multirow[t]{2}{*}{ IG2 } & ISG5 & $6 \mathrm{sp}$ & $\begin{array}{l}\text { Shrubs, sub canopy, annualreproductive phenophasesof } \\
\text { intermediate duration, zoochory, fleshy fruit }\end{array}$ \\
\hline & & ISG6 & $4 \mathrm{sp}$ & Herb, sub canopy, perennial, anemophily, anemochory, dried fruit \\
\hline
\end{tabular}


included shrubs, trees, and vines, most of them being perennial and occupying the canopy layer and producing fleshy fruits.

Cluster analysis of the interior region demonstrated the formation of two large functional groups, the first with 39 species distributed into four subgroups, and the second with 10 species divided into two subgroups (Fig. 3). Silhouette analysis, however, indicated that the ideal number of functional groups is five (Fig. 1b). The first functional group, IG1, includes the trees and vines composing the upper canopy, groups ISG1 and ISG2 produce dry fruits but differ in terms of their life forms, while ISG3 and ISG4 produced fleshy fruits but differ in terms of their leaf phenologies. The second functional group, IG2, is formed by herbs and shrubs of the subcanopy, differing principally by their pollination and dispersal syndromes and the types of fruits produced (Tab. 2). Considering the species co-occurring in both the edge and interior areas, $77.5 \%$ of them belong to the same functional group, with some species of
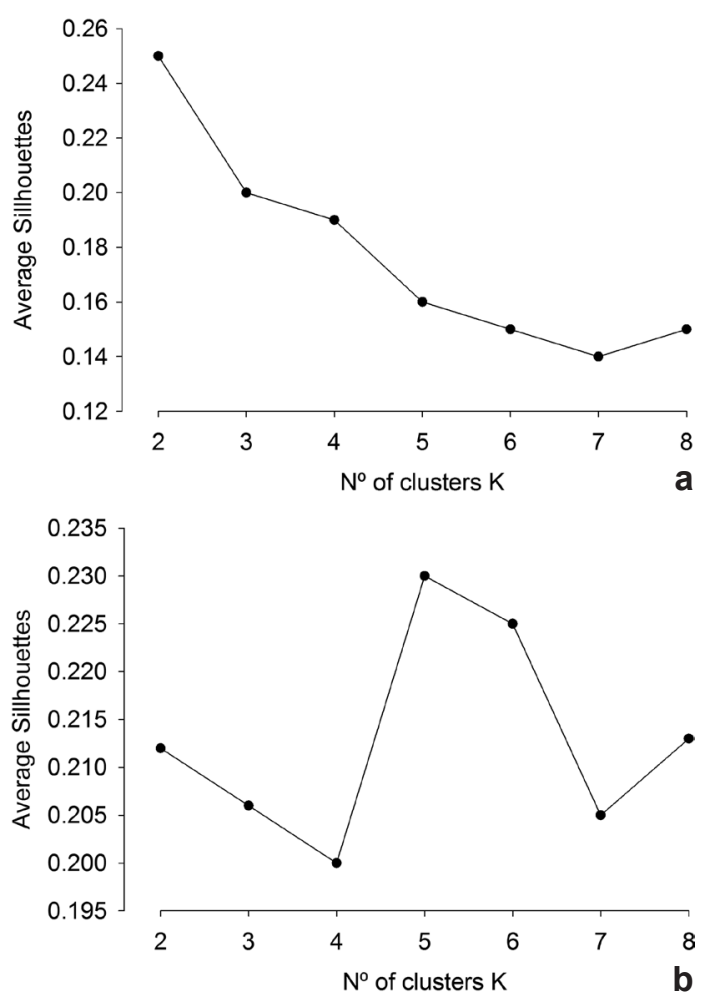

Figure 1 - a-b. Number of ideal cluster formed at the studied submontane seasonal forest, Chapada Diamantina, Northeastern Brazil, based on the Silhouette index $-\mathrm{a}$. border; $\mathrm{b}$. interior.
BSG2 [Myrcia obovata (Berg.) Niedz., Pouteria torta (Mart.) Radlk., Pouteria ramiflora (Mart.) Radlk.] forming a distinct group in the forest interior (ISG4).

The functional diversity indexes (Tab. 3) showed slightly higher average values in the edge environment although they were not statistically different, except FRic, which showed higher values in the forest interior and was statistically different from the edge and interior areas. The diversity indices were affected in terms of species richness and the Shannon diversity index (Tab. 3), except for the Shannon index in edge and interior areas for FDis (edge: $\mathrm{F}=0.5898 ; P=0,45$ and interior: $\mathrm{F}=3.103 ; P=0,0921)$.

\section{Discussion}

We found that the forest edge and interior had similar functional groups - indicating that despite the presence of different species in the edge and interior sites, they exercised similar ecological functions in both environments and demonstrated similar responses to environmental factors. Except in terms of richness, the other aspects of functional diversity (evenness, divergence, dispersion) were similar in both the forest edge and interior, suggesting no alterations in ecosystem services which contrasts with the literature (McCauley et al. 2013; Lopes et al. 2009). Our data indicated that although the forest edge had been colonized by a series of different species, it nonetheless maintained functional diversity patterns similar to those found in the forest interior; similar results were found for understory communities in an Atlantic forest (Prieto et al. 2014).

Grouping analysis showed that a single species could be placed in different groups (considering attributes of phenological synchrony, regularity, and duration) depending on whether its individuals grew in the forest interior or forest edge (Santos 2007; Vale et al. 2011). Numerous studies have shown that fragmentation exposes forest species to new environmental conditions and promotes changes in their reproductive traits (Reznik et al. 2012), and significant changes having been noted in the phenologies of plant species within border and interior contexts (Girão et al. 2007; Cara 2006; Reznik et al. 2012).

Due to the impacts of linear edges on floristic composition, diversity, and species abundance in the studied sites (Couto-Santos et al. 2015), and considering that sites closer to the edge will experience greater exposure to its effects (Pohlman 


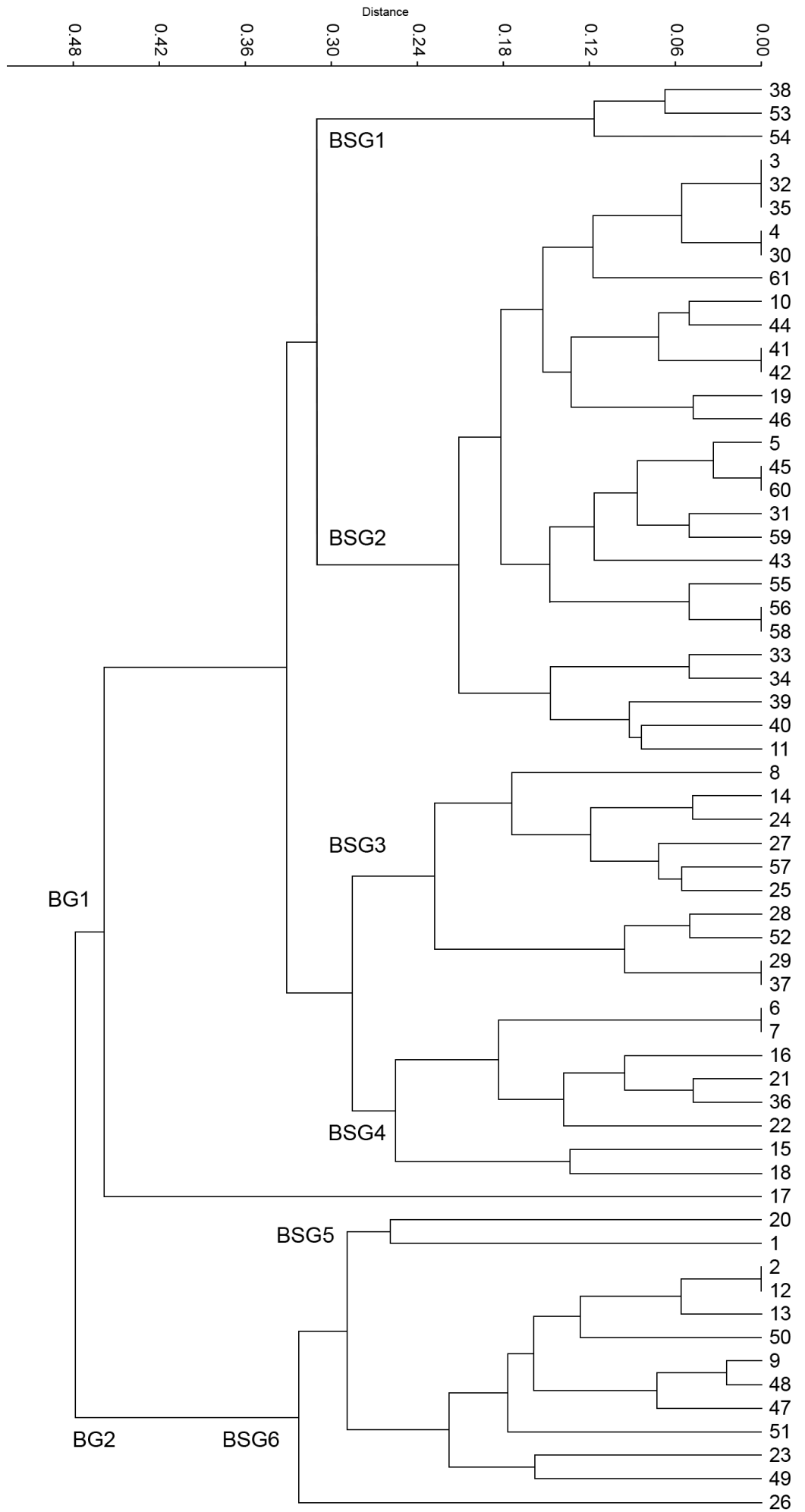

Figure 2 - Functional groups of plant species at the edge of a submontane seasonal forest, Chapada Diamantina, Northeastern Brazil. Groups defined by the Gower distance with numbered individuals as species listed in Appendix S1 (available on supplementary material < https://doi.org/10.6084/m9.figshare.13683961.v1>). BG = group; BSG = subgroups. 

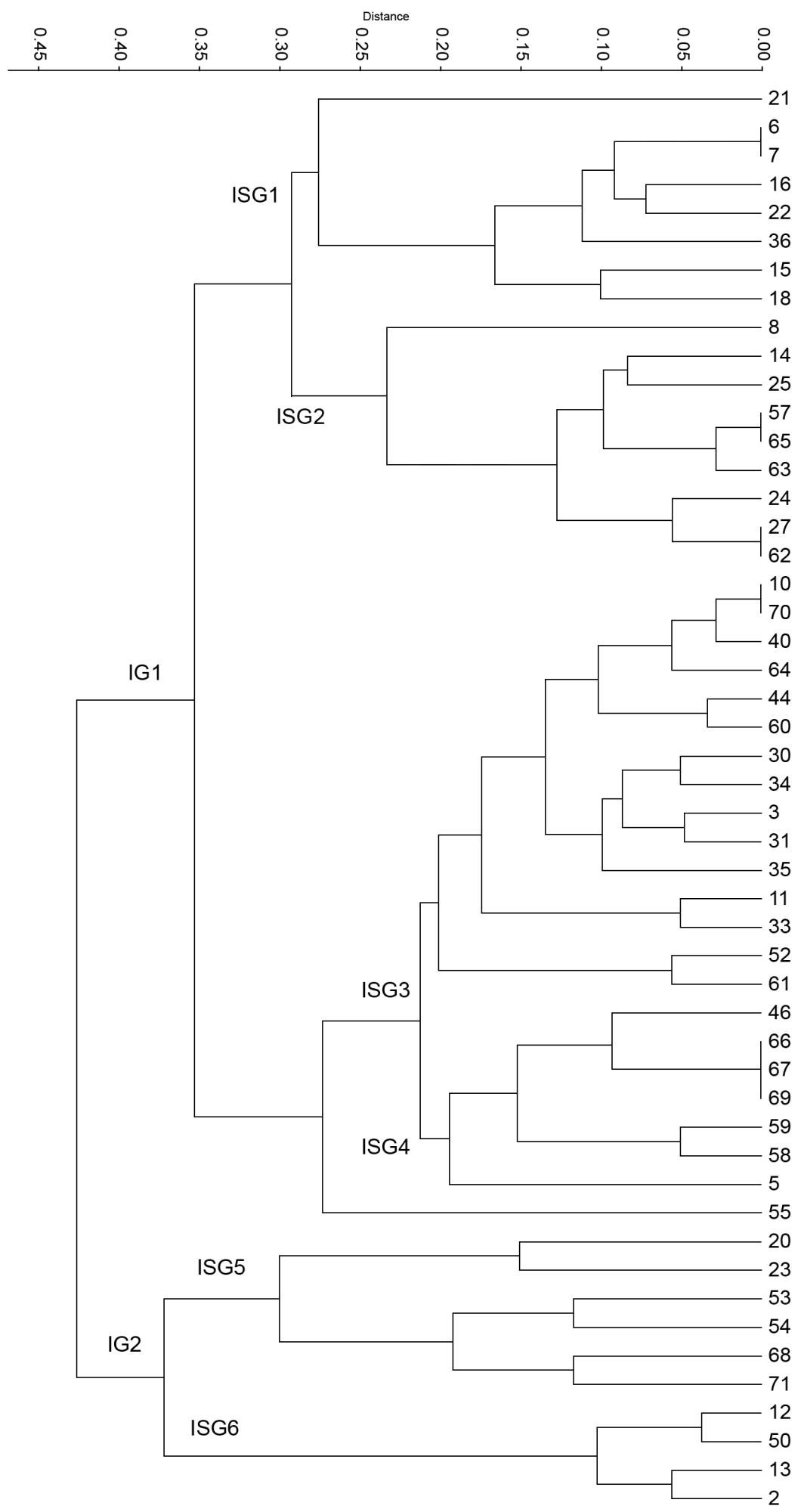

Figure 3 - Functional groups of plant species in the interior of a submontane seasonal forest, Chapada Diamantina, Northeastern Brazil. Groups defined by the Gower distance with numbered individuals as species listed in Appendix S1 (available on supplementary material <https://doi.org/10.6084/m9.figshare.13683961.v1>). IG = group; ISG = subgroup. 
Table 3 - Mean and standard deviation of functional diversity indices at the edges and in the interior of a submontane seasonal forest, Chapada Diamantina, Northeastern Brazil, analysis of variance of classification criterion (One-way ANOVA) between areas and between the diversity indices and species richness (S) and Shannon index (H'). Values significant $P<0.05$. FRic, FDiv, FEve and FDis refer to Functional richness, Functional divergence, Functional evenness and Functional dispersion.

\begin{tabular}{|c|c|c|c|c|c|}
\hline & & FRic & FDiv & FEve & FDis \\
\hline Edge & & $0.003 \pm 0.004$ & $0.80 \pm 0.04$ & $0.75 \pm 0.07$ & $2.46 \pm 0.3$ \\
\hline Interior & & $0.14 \pm 0.3$ & $0.77 \pm 0.06$ & $0.74 \pm 0.06$ & $2.36 \pm 0.3$ \\
\hline \multicolumn{6}{|c|}{ ANOVA } \\
\hline Edge X Interior & & $\begin{array}{c}\mathrm{F}=2.554 \\
P=0.001736\end{array}$ & $\begin{array}{l}\mathrm{F}=1.556 \\
P=0.222\end{array}$ & $\begin{array}{l}\mathrm{F}=0.233 \\
P=0.638\end{array}$ & $\begin{array}{l}\mathrm{F}=0.738 \\
P=0.596\end{array}$ \\
\hline \multirow{2}{*}{ Edge } & S & $\begin{array}{c}\mathrm{F}=143.2 \\
P=4.986 \mathrm{E}-08\end{array}$ & $\begin{array}{c}\mathrm{F}=126.3 \\
P=1.00 \mathrm{E}-07\end{array}$ & $\begin{array}{c}\mathrm{F}=127.2 \\
P=9.57 \mathrm{E}-08\end{array}$ & $\begin{array}{c}\mathrm{F}=93.72 \\
P=4.70 \mathrm{E}-07\end{array}$ \\
\hline & $\mathrm{H}^{\prime}$ & $\begin{array}{c}\mathrm{F}=838.3 \\
P=1.78 \mathrm{E}-12\end{array}$ & $\begin{array}{c}\mathrm{F}=364.5 \\
P=1.28 \mathrm{E}-10\end{array}$ & $\begin{array}{c}\mathrm{F}=375.3 \\
P=4.59 \mathrm{E}-11\end{array}$ & $\begin{array}{c}\mathrm{F}=0.5898 \\
P=0.45\end{array}$ \\
\hline \multirow{2}{*}{ Interior } & $\mathrm{S}$ & $\begin{array}{c}\mathrm{F}=114.5 \\
P=3.28 \mathrm{E}-07\end{array}$ & $\begin{array}{c}\mathrm{F}=101.6 \\
P=6.79 \mathrm{E}-07\end{array}$ & $\begin{array}{c}\mathrm{F}=102.2 \\
P=6.58 \mathrm{E}-07\end{array}$ & $\begin{array}{c}\mathrm{F}=70.23 \\
P=3.74 \mathrm{E}-06\end{array}$ \\
\hline & $\mathrm{H}^{\prime}$ & $\begin{array}{c}\mathrm{F}=289.2 \\
P=3.84 \mathrm{E}-14\end{array}$ & $\begin{array}{c}\mathrm{F}=259 \\
P=1.57 \mathrm{E}-09\end{array}$ & $\begin{array}{c}\mathrm{F}=271 \\
P=1.24 \mathrm{E}-09\end{array}$ & $\begin{array}{c}\mathrm{F}=3.103 \\
P=0.09207\end{array}$ \\
\hline
\end{tabular}

et al. 2007), it would be expected that the indexes of functional diversity would vary in relation to the forest edge and interior. Variations were only observed, however, in terms of Functional richness: ANOVA demonstrated that the linear edge did not affect other aspects of functional diversity indicating that the effects of that power line edge were less severe than edges formed between forests and open fields (Paciência \& Prado 2005; Ribeiro et al. 2009; Reznik et al. 2012). Similar patterns of edge effects have been described in tropical forest fragments (Laurance et al. 2006; Michalski et al. 2007; Oliveira et al. 2008).

From a biological point of view, as tropical forests are characterized by having stable microclimates and complex architectures (Laurance et al. 2009), linear edges surrounded by forest fragments will experience minimal microclimatic changes, having readily available seed sources for colonization - which will result in the similar functional structures observed here in the study area. Another relevant point to be considered is the time elapsed after the establishment of a linear edge. Recently created edges would tend to be structurally homogeneous (or at least very similar) to the forest interior (Holanda et al. 2010), but the power line that established the linear corridor in the seasonal forest investigated here was implanted approximately 50 years ago - sufficient time for alterations in the plant community to have occurred or for the forest to have established a new equilibrium. A study by Chazdon (2012), on the other hand, demonstrated that forest fragments can still show signs of change even $15-50$ years after a disruption event.

The similar functional diversities of the edge area and forest interior were visible in terms of their equivalent functional diversity indices, the co-occurrence of species, and the formation of functional groups based on similar attributes. The linear edge altered the functional richness and affected the diversity indices (S and $H^{\prime}$ ) without affecting other aspects of functional diversity, thus corroborating the study by Couto-Santos et al. (2015) that reported altered species composition, abundance, and distributions.

The greater functional richness index observed in the forest interior reflected biological losses caused by edge creation, as observed, for example, in the greater abundance of Casearia arborea (Rich) Urban, Copaifera langsdorffii Desf., Ocotea nitida (Meisn.) Rohwere, and Eschweilera tetrapetala Mori in the forest interior 
(Couto-Santos et al. 2015), the latter species is endemic to this unique forest fragment in Bahia State, and threatened with extinction (CNCFlora 2016). Menezes et al. (2018) demonstrated that climatic changes (due to ElNiño) and anthropogenic alterations (in this case related to edge creation) influenced the reproductive phenology and floral visitors of E. tetrapetala, whose flowering and fruiting were more intense in the forest interior (and it was visited by potential pollinators only in that context).

Considering the small sizes of the disjunct Atlantic Forest areas in the Espinhaço Range and threats of species extinctions, their conservation will require special attention (Coelho et al. 2018). The consequences of edge effects from linear canopy openings must be considered in conservation planning, especially in forest fragments (such as the present study, inserted in various matrix that largely determine the magnitude of edge effects) (Prieto et al. 2014). Although the forest fragment studied here is included within the boundaries of the Chapada Diamantina National Park and it is protected by the Atlantic Forest Act (Federal Law $\mathrm{n}^{\mathrm{o}} 11.428 / 2006$ ), its proximity to the main tourist attractions of the Chapada Diamantina generates immense anthropogenic pressure.

We concluded here that the seasonal tropical forest examined was more stable in terms of its functionality than its floristic composition (richness and diversity) after the establishment of the linear edge - indicating that edge effects from linear canopy openings provide excellent opportunities for field experiments to understand fragmented forest landscapes and help preserve diversity and function (Prieto et al. 2014). This research should therefore contribute to our understanding the impacts of linear edge creation and forest fragmentation on tropical forest communities.

\section{Acknowledgments}

The authors would like to thank the Conselho Nacional de Desenvolvimento Científico e Tecnológico (CNPq 480508/2008-09) and the Fundação de Amparo à Pesquisa do Estado da Bahia (FAPESB 5303/2009), for financing this research project; the Instituto Brasileiro do Meio Ambiente e dos Recursos Naturais Renováveis (IBAMA), for their permission to conduct the research; and the Chapada Diamantina Foundation, for accommodations and assistance with the fieldwork. $\mathrm{AAC}$ and LSF were supported by grants (PQ2) from $\mathrm{CNPq}$.

\section{References}

Anderson MJ (2001) A new method for nonparametric multivariate analysis of variance. Austral Ecology 26: 32-46.

Alvares CA, Stape JL, Sentelhas PC, Gonçalves JLM \& Sparovek G (2014) Köppen's climate classification map for Brazil. Meteorologische Zeitschrift 6: 711-728.

Athayde EA \& Morellato LPC (2014) Anthropogenic edges, isolation and the flowering time and fruit set of Anadenanthera peregrina, a cerrado savanna tree. International Journal of Biometeorology 58: 443-454.

Ayres M, Ayres JRM, Ayres DL \& Santos AAS (2007) Bioestat: aplicações estatísticas nas áreas das ciências bio-médicas. Sociedade Civil Mamirauá, Belém. 364p.

Borcard D, Gillet F \& Legendre P (2018) Numerical Ecology with R. $2^{\text {nd }}$ ed. Springer, New York. 452p.

Bussab WO \& Morettin PA (2017) Estatística básica. $9^{\text {th }}$ ed. Saraiva, São Paulo. 568p.

Cadotte MW, Carscadden K \& Mirotchnick N (2011) Beyond species: functional diversity and the maintenance of ecological processes and services. Journal of Applied Ecology 48: 1079-1087.

Cara PAA (2006) Efeito de borda sobre a fenologia, as síndromes de polinização e a dispersão de sementes de uma comunidade arbórea na floresta atlântica ao norte do Rio São Francisco. Tese de Doutorado. Universidade Federal de Pernambuco, Recife. 249p.

Carreño-Rocabado G, Peña-Claros M, Bongers F, Alarcón A, Licona JC \& Poorter L (2012) Effects of disturbance intensity on species and functional diversity in a tropical forest. Forest Journal of Ecology 100: 1453-1463.

Carvalho FA, Braga JMA \& Nascimento MT (2016) Tree structure and diversity of lowland Atlantic forest fragments: comparison of disturbed and undisturbed remnants. Journal Forest Research 27: 605-609.

Casanoves F, Pla L, Di Rienzo JA \& Díaz S (2011) Fdiversity: a software package for the integrated analysis of functional diversity. Methods in Ecology and Evolution 2: 233-237.

Charrad M, Ghazzali N, Boiteau V \& Niknafs A (2015) Package 'NBClust'. Available at $<$ https://cran.rproject.org/web/packages/NbClust/NbClust.pdf $>$. Access on 10 September 2019.

Chazdon RL (2012) Regeneração de florestas tropicais. Boletim do Museu Paraense Emílio Goeldi, Ciências Naturais 7: 195-218.

CNCFlora (2016) Eschweilera tetrapetala na Lista Vermelha da flora brasileira versão 2012.2 Centro Nacional de Conservação da Flora. Available at $<$ http:/cncflora.jbrj.gov.br/portal/pt-br/profile/ Eschweileratetrapetala>. Access on 23 October 2016. 
Coelho MS, Neves FS, Perillo LN, Morellato LPC \& Fernandes GW (2018) Forest archipelagos: a natural model of metacommunity under the threat of fire. Flora 238: 244-249.

Cordeiro NJ \& Howe HF (2001) Low recruitment of trees dispersed by animals in African forest fragments. Conservation Biology 15: 1733-1741.

Couto APL, Funch LS \& Conceição AA (2011) Composição florística e fisionomia de floresta estacional semidecídua submontana na Chapada Diamantina, Bahia, Brasil. Rodriguésia 61: 391405.

Couto-Santos APL (2014) Efeito de borda na estrutura, diversidade e fenologia de floresta tropical estacional submontana. Tese de Doutorado. Universidade Estadual de Feira de Santana, Feira de Santana. $128 \mathrm{p}$.

Couto-Santos APL, Conceição AA \& Funch LS (2015) The role of temporal scale in linear edge effects on a submontane Atlantic forest arboreal community. Acta Botanica Brasilica 29: 190-197.

Cunnigham SA (2000). Effects of habitat fragmentation on the reproductive ecology of four plant species in Mallec Woodland. Conservation Biology 14: 758-768.

Esseen PA, Karen AHR, Harper A, Christensen P \& Svensson J (2016) Factors driving structure of natural and anthropogenic forest edges from temperate to boreal ecosystems. Journal of Vegetation Science 27: 482-492.

Funch LS, Funch RR, Harley R, Giulietti AM, Queiroz LP, França F, Melo E, Gonçalves CN \& Santos $\mathrm{T}$ (2005) Florestas estacionais semideciduais. In: Juncá FA, Funch L \& Rocha W (eds.) Biodiversidade e conservação da Chapada Diamantina. Ministério do Meio Ambiente, Brasília. Pp. 181-193.

Funch LS, Rodal MJN \& Funch RR (2008) Floristic aspects of the forests of the Chapada Diamantina, Bahia, Brazil. In: Thomas W \& Briton EG (eds.) The Atlantic Coastal Forest of Northeastern Brazil. Memoirs of the New York Botanical Garden Press 100: 193-220.

Funch RR, Harley RM \& Funch LS (2009) Mapping and evaluation of the state of conservation of the vegetation in and surrounding the Chapada Diamantina National Park, NE Brazil. Biota Neotropica 9: 21-30.

Galetti M, Alves-Cost CP \& Cazetta E (2003) Effects of forest fragmentation, anthropogenic edges and fruit colour on the consumption of ornithocoric fruits. Biological Conservation 111: 269-273.

Girão LC, Lopes AV, Tabarelli M \& Bruna EM (2007) Changes in tree reproductive traits reduce functional diversity in a fragmented Atlantic forest landscape. PLoS One 2:908- 908.

Haddad NM, Brudvig LA, Clobert J, Davies KF, Gonzalez A, Holt RD, Lovejoy TE, Sexton JO,
Austin MP, Collins CD, Cook WM, Damschen EI, Ewers RM, Foster BL, Jenkins CN, King AJ, Laurance WF, Levey DJ, Margules CR, Melbourne BA, Nicholls AO, Orrock JL, Song DX \& Townshend JR (2015) Habitat fragmentation and its lasting impact on Earth's ecosystems. Science Advances 1: 1-9.

Hammer O, Harper DAT \& Ryan PD (2001) PAST: Paleontological statistics software package for education and data analysis. Palaeontologia Electronica 4: 1-9.

Holanda AC, Feliciano AP, Marangon LC, Santos MS, Melo CLSMS \& Pessoa MML (2010) de Estrutura espécies arbóreas sob efeito de borda em um fragmento de floresta estacional semidecidual em Pernambuco. Revista Árvore 34: 103-114.

IBGE (2012) Manual técnico da vegetação brasileira. $2^{\mathrm{a}}$ ed. Instituto Brasileiro de Geografia e Estatística, Rio de Janeiro. 271p.

Jara-Guerrero A, De la Cruz M \& Méndez M (2011) Seed dispersal spectrum of woody species in South Ecuadorian dry forests: environmental correlates and the effect of considering species abundance. Biotropica 43: 722-730.

Laurance WF, Lovejoy TE, Vasconcelos HL, Bruna EM, Didham RK, Stouffer PC, Gascon C, Bierregaard RO, Laurance SG \& Sampaio E (2002). Ecosystem decay of Amazonian Forest fragments: a 22-year investigation. Conservation Biology 16: 605-618.

Laurance WF, Nascimento HEM, Laurance SG, Andrade AC, Fearnside PM, Ribeiro JEL \& Capretz RL (2006) Rain Forest fragmentation and the proliferation of successional trees. Ecology 87 : 469-482.

Laurance WF, Goosem M \& Laurance SGW (2009) Impacts of roads and linear clearings on tropical forests. Trends in Ecology and Evolution 24: 659669.

Laurance WF, Camargo JLC, Luizão RCC, Laurance SG, Pimmd SL, Bruna EM, Stouffer PC, Williamson GB, Benítez-Malvido J, Vasconcelos HL, Van Houtan KS, Zartman CE, Boyle SA, Didhamm RK, Andrade A \& Lovejoy TE (2011) The fate of Amazonian forest fragments: a 32-year investigation. Biological Conservation 144: 56-67.

Lopes AV, Girão LC, Santos BA, Peres CA \& Tabarelli M (2009) Long-term erosion of tree reproductive trait diversity in edge-dominated Atlantic forest fragments. Biological Conservation. DOI: $<$ https:// doi.org/10.1016/j.biocon.2009.01.007>. Access on 20 August 2012.

Maeshiro R, Kusumoto B, Fujii S, Shiono T \& Kubota Y (2013) Using tree functional diversity to evaluate management impacts in a subtropical forest. Ecosphere 4: 1-17.

McCauley DJ, Power EA, Bird DW, McInturff A, Dunbar RB, Durham WH, Micheli F \& Young HS (2013) 
Conservation at the edges of the world. Biological Conservation 165: 139-145.

Melo DHA, Filgueiras BKC, Iserhard CA, Iannuzzi L, Freitas AVL \& Leal IR (2019) Effect of habitat loss and fragmentation on fruit-feeding butterflies in the Brazilian Atlantic Forest. Canadian Journal of Zoology 1: 588-596.

Mendes PGA, Silva MAM, Guerra TNF, Lins-e-Silva ACB, Cavalcanti ADC, Sampaio EVSB \& Rodal MJN (2016) Dynamics and Edge Effect of an Atlantic Forest Fragment in Brazil. Floresta Ambient. 23: 340-349.

Menezes IS, Couto-Santos APL \& Funch LS (2018) The influence of El Niño and edge effects on the reproductive phenology and floral visitors of Eschweilera tetrapetala Mori (Lecythidaceae), anendemic species of the Atlantic Forest of northeastern Brazil. Acta Botanica Brasilica 32: $1-11$.

Mori SA, Silva LAM, Lisboa G \& Coradin L (1989) Manual de manejo do herbário fanerogâmico. CEPEC/CEPLAC, Ilhéus. 104p.

Murcia C (1995) Edge effects in fragmented forests: implications for conservation. Tree 10: 58-62.

Oliveira MA, Santos AMM \& Tabarelli M (2008) Profound impoverishment of the large-tree stand in a hyper-fragmented landscape of the Atlantic forest. Forest Ecology and Management. 256: 1910-1917.

Oliveira-Filho AT \& Fontes MAL (2000) Patterns of floristic differentiation among Atlantic forests in Southeastern Brazil and the influence of climate. Biotropica 32: 793-810.

Paciência MLB \& Prado J (2005) Effects of forest fragmentation on pteridophyte diversity in a tropical rain forest in Brazil. Plant Ecology 180: 87-104.

Pérez-Harguindeguy N, Díaz S \& Garnier E (2013) New handbook for standardized measurement of plant functional traits worldwide. Australian Journal of Botany 61: 137-234.

Petchey OL \& Gaston KJ (2002) Functional diversity (FD), species richness and community composition. Ecology Letters 5: 402-411

Prieto PV, Sansevero JBB, Garbin ML, Braga JMA \& Rodrigues PJFP (2014) Edge effects of linear canopy openings on understorey communities in a lowland Atlantic tropical forest. Applied Vegetation Science 17: 121-128.

Pires JPA, Silva AG \& Freitas L (2014) Plant size, flowering synchrony and edge effects: what, how and where they affect the reproductive success of a Neotropical tree species. Austral Ecology 39: 328-336.

Pla F, Casanoves F \& Di Rienzo J (2012) Quantifying Functional Biodiversity. Springer Briefs in Environmental Science. Springer, Berlin. 98p.

Pohlman CL, Turton SM \& Goosem M (2007) Edge effects of linear canopy openings on tropical rain forest understory microclimate. Biotropica 39: 62-71.

R Core Team (2019) R: a language and environment for statistical computing. R Foundation for Statistical Computing, Vienna, Austria. Available at $<\mathrm{http}$ :/ www.R-project.org/>. Access on 22 September 2019.

Reznik G, Pires JPA \& Freitas L (2012) Efeito de bordas lineares na fenologia de espécies arbóreas zoocóricas em um remanescente de Mata Atlântica. Acta Botanica Brasilica 26: 65-73.

Ribeiro MT, Ramos FN \& Santos FAM (2009) Tree structure and richness in an Atlantic Forest fragment: distance from anthropogenic and natural edges. Revista Árvore 33: 1123-1132.

Santos BA, Peres CA, Oliveira MA, Grillo A, AlvesCosta CP \& Tabarelli M (2008) Drastic erosion in functional attributes of tree assemblages in Atlantic forest fragments of northeastern Brazil. Biological Conservation 141: 249-260.

Santos FRC (2007) Fenologia de espécies arbóreas do dossel e sub-dossel em um fragmento de mata atlântica semi-decídua em Caratinga, Minas Gerais, Brasil. Dissertação. Universidade Federal de Minas Gerais, Belo Horizonte. 100p.

Santos GGA, Santos BA, Nascimento HEM \& Tabarelli M (2012) Contrasting demographic structure of short and long-lived pioneer tree species on Amazonian forest edges. Biotropica 44: 771-778.

Sfair JC, Rosado BHP \& Tabarelli M (2016) The effects of environmental constraints on plant community organization depend on which traits are measured. Journal of Vegetation Science 27: 1264-1274.

Silveira FAO, Negreiros D, Barbosa NPU, Buisson E, Carmo FF, Carstensen DW, Conceição AA, Cornelissen TG, Echternacht L, Fernandes GW, Garcia QS, Guerra TJ, Jacobi CM, Lemos-Filho JP \& Stradic SL (2016) Ecology and evolution of plant diversity in the endangered campo rupestre: a neglected conservation priority. Plant Soil 403: 129-152.

Silveira MHB, Mascarenhas R, Cardoso D \& BatalhaFilho H (2019) Pleistocene climatic instability drove the historical distribution of forest islands in the northeastern Brazilian Atlantic Forest, Palaeogeography, Palaeoclimatology, Palaeoecology. Available at $<$ https://doi. org/10.1016/j.palaeo.2019.04.028>. Access on 02 July 2019.

Tabarelli M, Lopes AV \& Peres CA (2008) Edge-effects drive tropical forest fragments towards an earlysuccessional system. Biotropica 40: 657-661.

Tabarelli M, Mantovani W \& Peres CA (1999) Effects of Habitat Fragmentation and Plant Guild structure in the Montane Atlantic Forest of Southeastern Brazil. Biological Conservation 91: 119-127.

Vale VS, Dorneles MC, Schiavini I, Mendonça ET, Almeida CG, Silva PA \& Crespilho RF (2011) 
Grupos funcionais e sua importância ecológica na vegetação arbórea em um remanescente florestal urbano, Uberlândia, MG. Natureza on line 9: 67-75.
Violle C, Navas ML, Vile D, KazakouE, Fortunel C, Hummel I \& Garnier E (2007) Let the concept of trait be functional. Oikos 116: 882-892. 